\title{
HUSULI DAN HUDURI DALAM KONTEKS FILSAFAT HIKMAT MUTA'ALIYYAH
}

\section{HUSULI AND HUDURI IN THE WISDOM PHILOSOPHY OF MUTA'ALIYYAH CONTEXT}

Kholid Al Walid

kholid.alwalid@uinjkt.ac.id

UIN Syarif Hidayatullah

\begin{abstract}
ABSTRAK: Tulisan ini menjelaskan bagaimana pandangan Mulla Sadra dalam menjelaskan ilmu husuli dan ilmu huduri. Ilmu Husuli dan Huduri yang sejak lama menjadi perdebatan panjang di antara para pemikir muslim menjadi perhatian serius Mulla Sadra. Pendefinisian pengetahuan merupakan basis awal yang berusaha dibangun oleh Mulla Sadra dalam mengkontruksi aliran filsafat Hikmah alMuta'liyyah miliknya. Dengan pendekatan kualitatif dan melakukan kajian terhadap pemikiran dan karya-karya Mulla Sadra, dapat disimpulkan bahwa bagi Mulla Sadra perdebatan mengenai Husuli dan Huduri telah selesai dan tidak perlu diperlebar atau diperpanjang lagi. Husuli menempati posisis kedua yang menjadi ilmu pendukung, sedangkan huduri merupakan ilmu utama yang tertanam dalam diri manusia dan merupakan anugeran dari Tuhan.
\end{abstract}

Kata Kunci: Husuli, Huduri, Filsafat, Pengetahuan, Hikmah

ABSTRACT: This paper explains how Mulla Sadra's views in explaining husuli and huduri knowledge. The knowledge of Husuli and Huduri, which has long been a long debate among Muslim thinkers, is a serious concern of Mulla Sadra. The definition of knowledge is the initial basis that Mulla Sadra tries to build in constructing his philosophy of Hikmah al-Muta'liyyah. With a qualitative approach and conducting studies on Mulla Sadra's thoughts and works, it can be concluded that for Mulla Sadra the debate about Husuli and Huduri has been completed and does not need to be widened or extended any longer. Husuli occupies the second position which is the supporting science, while huduri is the main knowledge that is embedded in humans and is a gift from God.

Keyword: Husuli, Huduri, Philosophy, Knowledge, Hikmah

\section{A. PENDAHULUAN}

Pengetahuan merupakan bagian penting dalam proses manusia berpikir dan bertindak. Melalui pengetahuan, manusia akan dapat menerima sesuatu yang menurutnya logis dan dapat dilakukan sehingga ia dapat memaksimalkan akal yang dimilikinya dan memfungsikannya dengan baik. Praktinya, banyak kalangan yang berbeda pendapat mengenai ilmu dan pengetahuan. Sejarah mencatat bahwa di antara para pemikir Islam dan Barat terjadi perdebatan panjang mengenai definisi ilmu dan pengetahuan.

Filsafat Islam sebagai salah satu cabang peradaban khazanah pemikiran Islam termasuk dalam kelompok yang ambil bagian dalam perdebatan mengenai pengetahuan. 
Sejak masa Ibn Sina hingga akhirnya pada masa Mulla Sadra, beragam pemikiran dan pandangan lahir untuk menjelaskan pengetahuan yang menjadi dasar dan sumber manusia untuk berpikir dan mengenal Tuhannya.

Pengetahuan menjadi pembahasan penting dalam filsafat Islam karena menjadi pondasi awal sebelum manusia memahami segala sesuatu, Tulisan ini akan menjelaskan bagaimana pandangan Mulla Sadra mengenai ilmu pengetahuan khususnya ilmu husuli dan ilmu huduri.

\section{B. METODE PENELITIAN}

Dalam merumuskan dan menyusun artikel ini, penulis menggunakan metode kualitatif dengan menguraikan dan menjelaskan permasalahan yang ada, kemudian penulis analisis dengan pendekatan filsafat Hikmah Muta'aliyyah.

\section{HASIL DAN PEMBAHASAN}

\section{Mulla Sadra dan Filsafat Hikmah Muta'aliyyah}

Perkembangan filsafat pasca Ibn Sina dan Suhrawardi terus berkembang. Belakangan, Mulla Sadra seorang filosof mengembangkan filsafat Islam dan melahirkan sebuah sekolah baru dalam aliran filsafat yang dikenal dengan Hikmah Muta'aliyyah.

Kehadiran Mulla Sadra ini menurut Syaifan Nur menunjukkan bahwa sebenarnya filsafat Islam tidak mati meski mendapat serangan dari Al Ghazali pada abad ke-5 H/11 M, kematian Ibn Rusyd pada abad 6 H/12 M, atau invasi Mongol pada abad $13 \mathrm{M}^{1}$

Menurut Nasr, membangun teosofi transenden atau al Hikmah al Muta'aliyyah yang merupakan mazhab baru yang didasarkan pada penafsiran baru terhadap pandangan tradisional. Ini hanya bisa dibangun oleh orang yang benar sebagai pembaharu.yang melahirka sebuah gagasan atau prespektif intelektual baru yang tidak bertentangan dengan Islam, pada saat yang sama juga selaras dengan logika dan syarat penglohatan spiritual, sebuah kombinasi langka yang mampu dilakukan oleh Mulla Shadra. ${ }^{2}$

\footnotetext{
${ }^{1}$ Syaifan Nur. Filsafat Hikmah Mulla Shadra. Yogyakarta: RausyanFikr Institute, 2012. H. 9.

${ }^{2}$ Seyyed Hossein Nasr. Al-Hikmah Al-Muta'aliyyah Mulla Sadra: Sebuah Terobosan dalam Filsafat Islam. Terj. Mustamin al Mandary. Jakarta: Sadra Press, 2017. H. 13.
} 


\section{Pengetahuan dan Proses Manusia Mencerap Pengetahuan}

Menurut Sadra, proses memperoleh pengetahuan dapat dilakukan dengan tiga cara, yaitu; pertama, dimulai dari pengalaman rohani kemudian dicari dukungan rasio, dan kemudian diselaraskan dengan syariat, kedua, diawali dari pemikiran rasional kemudian dihayati dengan pengalaman rohani, dan kemudian dicari dukungan syariat, ketiga, bermula dari ajaran syariat kemudian dirasionalkan, dan seterusnya dipertajam dengan penghayatan rohani. Artinya, Sadra dalam membangun pemikiran epistemologinya berupaya mendamaikan metode filosofis dan metode sufistik (metode burhani dan 'irfani), dan kemudian diselaraskan dengan syariat Islam. Baginya kebenaran hanya dapat dipahami dengan menggabungkan dan mengapresiasi secara seimbang antara metode filosofis dan metode sufistik dengan tetap mengikuti panduan syariat Islam. ${ }^{3}$

Ada dua definisi Ilmu yang biasanya dikemukakan Mulla Shadra maupun para filosof yang mendasarkan bangunan filsafatnya atas dasar filsafat Al-Hikmat al-Muta'aliyat antara lain ${ }^{4}$ : Al-Ilmu ibarat an hudhuru shuratu syai li al-Mudrik (Ilmu merupakan hadirnya gambaran sesuatu pada pencerap) atau Hudhuru Surat al-Syai inda al-Aql (Hadirnya gambaran sesuatu pada akal). Kedua definisi sebenarnya memiliki makna yang sama bahwa ilmu pada intinya adalah gambaran objek pada mental subjek. Mulla Shadra berdasarkan konsepsi pengetahuan membagi ilmu ke dalam beberapa bagian antara lain :

\section{Tashawur dan Tashdiq (Konsepsi dan Konfirmasi)}

Ilmu dari segi penilaian dan penetapan hukum dapat di bagi menjadi dua bagian ; Tashawur (Konsepsi) dan Tashdiq (Konfirmasi). Keduanya berbeda baik dari segi substansi maupun efek yang muncul. Konsepsi merupakan ilmu yang bebas dari segala bentuk penilaian salah dan benar, pada substansinya kita tidak dapat mendegasikan salah atau benar dari konsep-konsep yang hadir pada mental. Konsepsi sendiri terbagi ke dalam beberapa bagian :

a. Konsepsi yang tidak memiliki relasi dan bersifat independent, seperti konsepsi tentang : Manusia, Hewan dan sebagainya.

${ }^{3}$ Dudi Badruzaman. Perkembangan Paradigma Epistemologi Dalam Filsafat Islam. IDEA: Jurnal Humaniora, Vol 2, No.1, April 2019. 60 .

${ }^{4}$ Mulla Shadra, Op Cit, j. 6 h. 151 dan, Manthiq Nuwin, (Tehran : Markaze tahqiqat, 1365) h. 25. 
b. Konsepsi yang memiliki diferensia (Fashl) seperti : Hewan Rasional.

c. Konsep yang memiliki relasi perintah seperti : Pukullah, pergilah dan sebagainya.

d. Konsepsi yang memiliki relasi berita seperti : Zaid Berdiri, terjadi konsepsi tentang "Zaid" "berdiri" dan relasi diantara keduanya.

Sedangkan "Tashdiq" (Penilaian) adalah ilmu yang didasarkan penilaian salah dan benar terhadap relasi yang terjadi atau mungkin aktualisasinya atau ketidak mungkinan aktualisasinya.

\section{Ilmu Dharuri (Keharusan) dan Iktisabi (Proses)}

Ilmu Dharuri (Keharusan) yaitu ilmu yang terhasilkan bukan melalui proses berfikir dan mengkonsepsi akan tetapi hadir secara langsung, seperti gambaran kita tentang sesuatu, Tidak mungkinnya bergabung dua hal yang bertentangan, Universal lebih luas dari parsial, satu merupakan setengah dari dua dan sebagainya. Ilmu Keharusan ini terbagi lagi kedalam beberapa bagian :

a. Al-Awaliat (Permulaan)

Aksioma yang diperoleh akal tanpa bantuan sesuatu yang eksternal darinya, seperti : Tidak mungkinnya bersatu dua hal yang bertentangan.

b. Al-Musyahadat (Penyaksian)

Aksioma yang didapat berdasarkan penilaian akal dengan bantuan indra dan tidak cukup hanya engkonsepsian dua bagian dengan relasi diantaranya.

c. Al-Tajribiat (Eksperimental)

Aksioma yang didapat berdasarkan bantuan eksperimen, seperti :Air menguap ketika dipanaskan, dan sebagainya.

d. Al-Hadsiat (Analisa)

Aksioma yang didapat berdasarkan aanalisa seperti : Cahaya rembulan berasal dari cahaya matahari.

e. Al-Fitriat (Fitrah)

Aksioma yang didapat melalui bantuan perantara yang jika perantara tersebut hadir dalam mental maka hadirlah aksioma ini, seperti : Lima setengah dari sepuluh. 
Sedangkan "Iktisabi” (Proses) atau "Nazhari” (Pemikiran), merupakan ilmu yang diperoleh berdasarkan hasil proses berfikir seperti : Rotasi bumi mengelilingi matahari, tingkat getaran gelombang suara dan sebagainya. Iktisabi sendiri terbagi kedalam dua bagian dasar :

a. Al-Tashawur al-Kasbi (Konsepsi Proses)

Konsepsi yang didasarkan pada dua unsur utama yaitu Had (Batasan Substansial) dan Rasm (Batasan Aksidental)

b. Al-Tashdiq al-Kasbi (Penilaian Proses)

Penilaian terhadap konsepsi yang didasarkan pada Qiyas (Silogisme) Istiqra' (Sampling) dan Tamsil (Permisalan)

\section{Ilmu Fi'li (Aktif) dan Infi'ali (Pasif)}

Ilmu Aktif yaitu ilmu yang pada dirinya terdapat sebab sempurna yang eksisten di dalam mental dengan eksistensi akibat eksternal, seperti : Ketika seseorang yang memiliki ilmu ini melihat secara eksternal seseorang yang berdiri di atas atap dan dikonsepsikan bahwa dia terjatuh, maka segera segera orang tersebut terjatuh atau membayangkan sendok eksternal menjadi bengkok dan segera sendok tersebut menjadi bengkok.

Ilmu Pasif merupakan kebalikan dari Ilmu aktif yaitu yang tidak memiliki sebab sempurna di dalam dirinya seperti: seorang Arsitek yang menggambarkan didalam mentalnya sebuah bangunan dan bangunan tersebut hanya terbangun di dalam mentalnya saja tanpa pengaruh eksternal langsung.

4. Ilmu Kulli (Universal) dan Juz'I (Parsial)

Ilmu Universal yaitu akal tidak membatasi terhadap kebenaran generalisasisanya pada objek yang plural, seperti : Manusia, Hewan dan sebagainya.

Ilmu Parsial yaitu akal membatasi generalisasinya pada objek yang plural, seperti : Ilmu terhadap Muhammad, Zaid, Sapi, Gajah dan sebagainya.

\section{Ilmu Tafshili (Spesifik) dan Ijmali (Umum)}

Ilmu Spesifik yaitu ilmu yang berkaitan dengan objek-objek tertentu yang berbeda satu sama lain dalam spesifikasi perbedaannya. Sedangkan Ilmu Ijmali yaitu ilmu yang berkaitan tentang objek-objek yang berbeda dalam sebuah kesatuan. 


\section{Ilmu Ilmi (Ilmiah) dan Ilmu Amali (Tindakan)}

Ilmu Ilmiah yaitu ilmu yang hanya merupakan konsepsi ilmiah semata dan berkaitan dan memberikan kesempurnaan jiwa bagi manusia seperti : Ilmu Ketuhanan dan yang berkaitan dengannya dan sebagainya.

Ilmu Tindakan yaitu ilmu yang menuntut aktualisasi dalam tindakan seperti : Ilmu tentang keadilan yang wajib ditegakkan oleh seorang pemimpin dan sebagainya.

\section{Ilmu Haqiqi (Hakiki) dan I'tibari (Relatif)}

Ilmu Hakiki yaitu ilmu yang berkaitan dengan eksistensi dan derajatderajatnya sedangkan Ilmu Relatif yaitu ilmu yang berkaitan dengan sesuatu yang bersifat relatif dan bergantung pada konsensus.

Ada jenis pembagian ilmu lain yang didasarkan terhadap eksistensi yang sebelumnya pada penjelasan tentang Eksistensi Mental kita sudah membagi objek berdasarkan eksistensinya kedalam dua jenis: eksternal dan mental. Dalam kerangka dua bentuk eksistensi seperti itulah pembagian ini terjadi. Secara khusus Mulla Shadra memberikan isyarat pembagian tersebut ketika mengomentari pandangan Ibn Sina :

"Dan pernyataannya yang diperoleh dari Syaikh (Ibn Sina) pada banyak bagian dari kitab-kitabnya bahwa bentuk eksistensial eksternal seperti yang diperoleh dari langit dan bagian-bagiannya serta bentuk-bentuk eksternalnya melalui indera dan pengamatan atas bentuk rasionalnya dan pada bagian lain bahwa bentuk visual objek yang tercerap tidak berdasarkan indera akan tetapi sebaliknya seperti bentuk visual dari rumah yang akan dibangun, hadir lebih dahulu pada mental karena kemampuan imajinatif dan bentuk visual tersebut memotivasi anggota tubuh untuk melakukan aktivitas sampai pada realisasinya secara eksternal. Tidaklah bentuk visual ilmiah tersebut berasal dari objek eksternal akan tetapi justru eksistensi eksternalnya yang mengikuti eksistensi mental sebagaimana yang telah dijelaskan pada persoalan kualitas mental"

Pembagian yang dilakukan Mulla Shadra di atas dikategorikan kedalam dua jenis ilmu yaitu : Ilmu Husuli (Korespondensi) dan Ilmu Hudhuri (Kehadiran). 
Kedua bagian ilmu inilah yang merupakan awal pembicaraan konsep Ittihad alÂqil wa al-Ma'qul.

\section{Ilmu Husuli (Korespondensi)}

Ilmu Husuli adalah ilmu atau pengetahuan yang didapat berdasarkan proses korespondensi yang terjadi antara subjek dengan objek eksternal. Antara keduanya terdapat eksistensi independent yang berbeda dan tidak berkaitan satu sama lain. Keduanya memiliki dimensi dan derajat spesifik dalam kemaujudan dirinya dan tidak bergantung satu sama lain atau dapat kita sebutkan tidak adanya hubungan kausalitas di antara keduanya. Ketidak terikatan dua eksistensi tersebut meliputi seluruh hal baik ontologis, epistemologis dan logis sehingga tidak mungkin secara rasional kedua objek tersebut menjadi sebuah kesatuan karena jika tidak, akan terjadi Inqilab (Perubahan dengan penghilangan eksistensi dan identitas yang satu kepada yang lain) hal ini jelas tidak mungkin, seperti yang dinyatakan Mulla shadra :

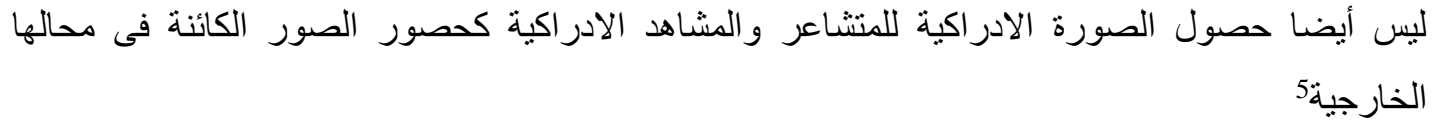

"Dan juga bukan sampainya bentuk-bentuk pencerapan bagi subjek dan penyaksi proses pencerapan seperti sampainya bentuk alam semesta dalam dimensi eksternalnya"

Pada bagian lain Mulla Shadra juga menjelaskan :

$$
\text { العلم عبارة عن حضور صورة شيء للمدرك6 }
$$

"Ilmu merupakan gambaran dari visual yang terhasilkan dari sesuatu pada diri subjek"

Ilmu pada makna ini merupakan korespondensi antara objektif subjek dan objektif objek. Objektif subjeklah yang melakukan proses pencerapan sehingga menimbulkan korespondensi keduanya. Allamah Thabathaba'i menjelaskan ilmu Husuli sebagai berikut :

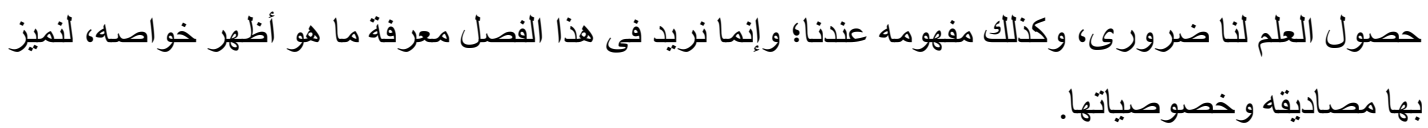

${ }^{5}$ Ibid., h. 299.

6 Ibid., J. VI, h. 151. 


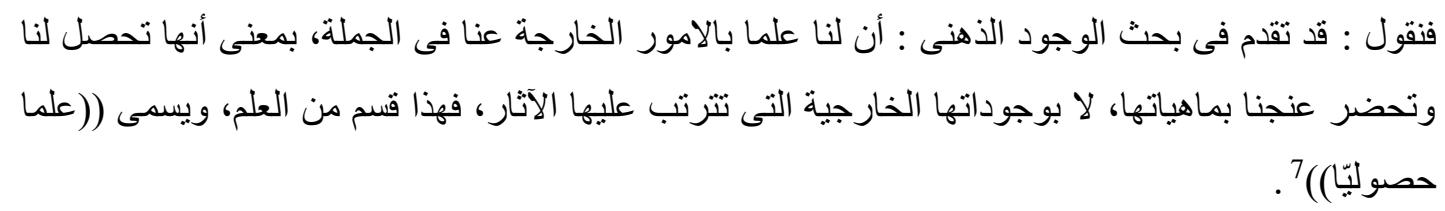

"Kami katakan : Sebagaimana telah dibicarakan pada pembahasan Eksistensi Mental : Bahwa sesungguhnya kita memiliki ilmu terhadap persoalan eksternal yang berada di luar diri kita, bermakna tersampaikan dan terhadirkan pada diri kita dalam bentuk aksidennya dan bukan eksistensi eksternalnya yang memiliki efek, bagian ilmu ini disebut Ilmu Korespondensi”

Allamah Thabathaba'i menyebutkan bahwa dalam korespondensi itu objek yang diserap oleh subjek merupakan visualisasi Entitas dari objektif objek sebagai eksistensi eksternal karena tidak mungkin yang terserap dan masuk pada mental subjek tersebut adalah eksistensi eksternal karena eksistensi eksternal memiliki efek yang hanya terjadi pada dimensi eksternal dan tidak terjadi pada dimensi mental. Dengan demikian yang terserap pada subjek bukanlah eksistensi eksternal objek akan tetapi bentuk visual entitas objek. Inilah makna Ilmu Korespondensi.

\section{Ilmu Hudhuri (Kehadiran)}

Berbeda dengan Ilmu korespondensi bahwa yang hadir pada mental subjek adalah bentuk visual entitas objek tapi pada Ilmu Kehadiran yang hadir pada mental subjek adalah eksistensi objek.

Dari definisi dan gambaran sederhana di atas kita dapat membedakan secara substansial antara ilmu Hudhuri dengan Ilmu Korespondensi, beberapa ciri utama Ilmu Hudhuri antara lain bahwa : 1. Dia hadir secara eksistensial di dalam diri Subjek. 2. bukan merupakan konsepsi yang dibentuk dari silogisme yang terjadi pada mental. 3. kebebasan dari dualisme kebenaran dan kesalahan.

Tiga ciri utama tersebut terjadi karena tidak adanya lagi pemisahan dua objek eksternal dan internal. Kita ambil contoh rasa sakit yang kita derita, secara epistemologis pertama, kita mengetahui rasa sakit tersebut hadir secara eksistensial di dalam mental kita dan sama sekali kita tidak akan pernah dapat

${ }^{7}$ Muhammad Husayn Thabathaba'i, Bidayat al-Hikmat, (Qom : Muasasat Nashr al-Islami, 1415) h. 138. 
menemukannya dalam eksistensi eksternalnya. Kedua, rasa sakit itu tidaklah dibentuk berdasarkan beberapa proposisi yang kita negasikan satu sama lain sehingga membentuk rasa sakit. Ketiga, karena kehadirannya secara eksistensial tentulah tidak lagi terjadi penilaian benar dan salah sebagaimana yang terjadi pada Korespondensi ketika kita melakukan negasi antara objek yang ada pada mental dengan objek eksternalnya.Allamah Thabathaba'i mendeskripsikan Ilmu Hudhuri sebagai berikut :

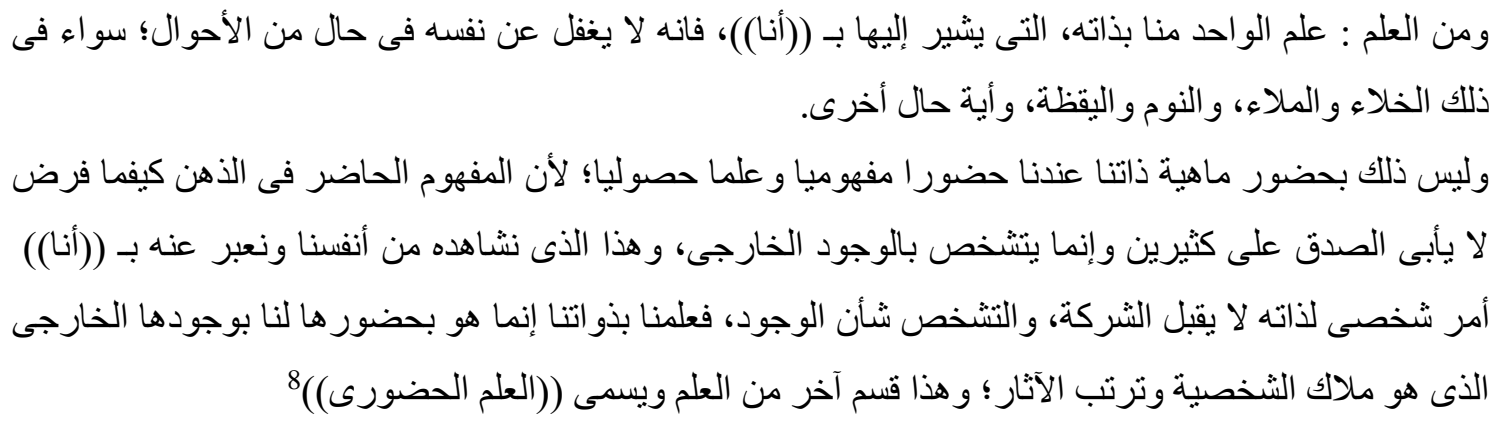

"Dari bagian ilmu : Satu bentuk ilmu pada kita (hadir) dengan esensinya yang di isyaratkan dengan (Aku) karena sesungguhnya dia (Aku) tidak pernah hilang dari diri kita dalam kondisi apapun ; baik dalam kesendirian maupun dalam kesibukan, tidur ataupun terjaga, atau keadaan apapun lainnya. Dan yang demikian itu bukanlah hadirnya aksiden esensi (Aku) pada diri kita dalam bentuk hadirnya mafhum dari ilmu korespondensi: karena mafhum yang hadir pada mental bagaimanapun kita gambarkan tidak akan lepas dari relasinya dengan yang plural dan teridentitaskan dalam eksistensi eksternal, dan hal ini yang kita saksikan dari diri kita yang kita sebut dengan (Aku) merupakan identitas yang pada esensinya tidak terkomposisi dan teridentitas dalam dimensi eksistensi, maka kita memiliki ilmu terhadap esensi kita (Aku) dan hadir pada diri kita dengan eksistensi eksternal yang merupakan dasar identitas yang memiliki efek : dan ini merupakan satu jenis yang lain dari ilmu yang disebut Hudhuri”

$A k u$ tentulah merupakan eksistensi mental yang ada pada setiap diri, kehadirannya tidak hanya secara entitas tapi jelas secara eksistensial, karena itu objektif objek bukanlah sesuatu yang berada diluar diri objektif subjek, dia hadir dan

${ }^{8}$ Muhammad Husayn Thabathaba'i, Op Cit., h. 139. 
merupakan bagian kita yang tidak terpisahkan. Karena kehadirannya secara eksistensial tentulah tidak terjadi korespondensi yang memisahkan keduanya. Mulla Shadra secara khusus menjelaskan kehadiran eksistensial tersebut :

“...Eksistensi tidak mungkin dapat dipersepsi melalui aksidennya kecuali bedasarkan kedirian eksistensialnya dan bukan dari imajinasi mental baginya. Eksistensi tersebut jika kita imajinasikan kehadirannya di dalam akal kita maka tidaklah ada keraguan bagi kita bahwa kita mengetahui berdasarkan esensinya, mengetahui dalam konteks ini tidaklah membutuhkan argumen"

Bagi Mulla Shadra kesadaraan terhadap Aku merupakan sebuah kesadaran yang paling mendasar yang dimiliki semua manusia dan bersifat jelas tanpa perlu sebuah proses berfikir. Dalam kontek seperti ini pada diri kita terdapat kehadiran yang paling jelas karena seperti yang disebutkan diatas kehadiran objek tersebut (Aku) bukan lagi sesuatu yang asing dan terpisah dari diri subjek.

Meskipun berdasarkan karakteristik diantara ilmu Husuli dengan ilmu Hudhuri kita mendapati perbedaan mendasar, akan tetapi secara substansial menurut para filosof Al-Hikmat al-Muta'aliyat, Ilmu Husuli sebagai ilmu yang didapat berdasarkan proses korespondensi dengan objek eksternal pada prinsipnya kembali dan berasal dari Ilmu Hudhuri, karena pengetahuan yang terhasilkan pada diri subjek merupakan bentuk dari sebuah objek yang hadir di dalam mental subjek, kehadirannya pada alam mental tersebut tidak lain kecuali dalam bentuk eksistensi mental, sehingga persepsi subjek terhadap objek yang masuk merupakan persepsi terhadap eksistensi mental dan hal tersebut merupakan makna ilmu Hudhuri. Seperti juga yang dinyatakan Allamah Thabathaba'i

"Kemudian, terhasilkannya ilmu pada diri kita bermakna : sampainya objek pada diri kita, karena ilmu merupakan identitas objek secara substantif sedangkan tidaklah yang kita maksudkan ilmu kecuali terhasilkannya objek pada diri kita dan terhasilnya atau hadirnya objek tidak lain kecuali dalam eksistensinya dan eksistensi tersebut merupakan dirinya"

Objek yang hadir pada diri subjek merupakan visual yang diciptakan mental sebagai eksistensi mental dari eksistensi eksternal dan tentu saja kehadiran yang terjadi pada diri subjek kehadiran eksistensial sehingga persepsi subjek bukan terhadap eksistensi eksternal akan tetapi pada eksistensi mental yang hadir. 
Berdasarkan hal tersebut kita dapat menyatakan bahwa Ilmu Husuli pada prinsipnya kembali dan berasal dari Ilmu Hudhuri, karena ketika visual entitas eksternal masuk ke dalam jiwa subjek, jiwa melakukan proses penciptaan eksistensi mental objek. Untuk ini Mulla Shadra dan para pengikutnya mengemukakan beberapa argumen berikut ini $^{9}$ :

1. Objek eksternal merupakan eksistensi eksternal, pencerapan melalui proses korespondensi menyampaikan pada diri subjek bentuk visual dari objek. Bentuk visual bukanlah substansi objek karena substansinya adalah eksistensinya. Jika pengetahuan subjek terhadap objek didasarkan kepada bentuk visual entitas yang hadir sementara bentuk entitas objek bukanlah objek itu sendiri maka subjek tidak memiliki ilmu terhadap objek eksternal tersebut, hal ini akan berujung pada skeptisisme.

2. Objek eksternal terikat pada ruang dan waktu serta mengalami proses perubahan dengan perjalanan waktu, akan tetapi pada objek mental yang merupakan bentuk ilmiah dari objek eksternal tidak bergantung pada ruang dan waktu serta bersifat tetap, sehingga kapanpun dan dimanapun ketika subjek menginginkan kehadirannya objek mental tersebut akan hadir pada diri subjek. Hal tersebut membuktikan bahwa objek yang hadir pada diri subjek merupakan eksistensi mental dari eksistensi eksternal objek.

3. Dari bentuk mental yang hadir pada diri subjek, subjek dapat melakukan perubahan sehingga membentuk jenis eksistensi baru padahal objek eksternal tetap dalam kondisinya semula. Jika objek mental terikat pada objek eksternal tentulah tidak dapat terjadi perubahan apapun sesuai dengan kondisi objek eksternal.

4. Objek eksternal memiliki efek spesifik seperti langit yang luas, bumi yang besar, bahtera yang tanpa batas, gunung yang tinggi. Dalam proses Husuli tentulah tidak mungkin tercerapnya bentuk tersebut sebagaimana eksistensi eksternal dan jika yang dipersepsi oleh mental hanya visual entitas kita kembali pada argumentasi pertama. Karenanya jiwalah yang menciptakan eksistensi mental dari eksistensi eksternal tersebut.

${ }^{9}$ Mulla Shadra, Op Cit. J. III, h. 300-304, Muhammad Husayn Thabathaba'i, Nihayat al-Hikmat, (Qom : Muasasat Nashr Islami, 1415) h. 236-240. Ja'far Subhani, Nazhariyat al-Ma'rifat (Qom : Markaz al-Alami li al-Dirasat al-Islamiyah, 1411) h. 37-50. 
5. Mental dapat melakukan pemilahan-pemilahan antara aksiden dengan substansi yang terdapat pada objek mental. Misalnya, mental dapat memisahkan warna biru dari langit dari objek eksternal langit biru yang tidak mungkin terpisah antara aksiden dan substansinya.

Mulla Shadra dalam kaitan ini menyebutkan :

"Sesungguhnya bentuk visual material yang besar tidak akan terhasilkan pada materi kecil, tidak mungkin gunung masuk pada titik-titik debu, tidak juga samudera dapat masuk kedalam kolam, hal seperti ini bertolak belakang dengan eksistensi pencerapan karena sesungguhnya reseptivitas jiwa sama antara yang besar dan kecil. Jiwa memiliki kemampuan untuk menghadirkan pada imajinasinya visual dari langit maupun bumi dan apapun diantara keduanya dalam sekejap tanpa kehilangan satupun darinya sebagaimana yang digambarkan pemimpin dan penghulu kita Muhammad Saw. : 'Sesungguhnya hati mukmin lebih besar dari Arsyi' dan seperti juga yang diucapkan Abu Yazid Bustami dalam menceritakan dirinya 'Kalau saja Arsyi dan selainnya berada di sudut diantara sudutsudut hati Abu Yazid tidaklah akan terasa baginya'. Karena sesungguhnya kita mengetahui bahwa jiwa dari diri kita merupakan identitas yang satu jika mencerap sesuatu yang berukuran besar mencerap seluruhnya tanpa kecuali dan bukan hanya sebagiannya saja karena tidak ada sebagian baginya disebabkan kesederhanaannya."

Argumentasi Mulla Shadra memberikan bukti terhadap eksistensi mental sekaligus juga menunjukkan bahwa Ilmu yang ada pada diri kita adalah Ilmu Hudhuri. Ilmu Husuli berfungsi hanya sebagai causa bagi jiwa untuk melakukan kreatifitasnya dalam mewujudkan eksistensi mental dari objek eksternal.

\section{SIMPULAN}

Pengetahuan merupakan diskursus yang telah banyak dibahas bahkan sejak masa filsafat Yunani hingga memasuki pemabahasan dalam filsafat Islam. Epistemologi merupakan bagian dari pembahasan filsafat. Dalam konteks filsafat Islam, khususnya Mulla Sadra, ada dua jenis ilmu yang dimiliki oleh manusia, yaitu ilmu Hushuli dan ilmu Hudhuri. Ilmu Hushuli menurut Mulla Sadra merupakan ilmu tambahan atau ilmu penunjang bagi manusia memaksimalkan kreatifitasnya. Ilmu yang paling utama dan 
sudah sejak lama tertanam dalam diri manusia adalah ilmu Hudhuri. Ilmu Hudhuri telah tertanam dalam diri manusia untuk menjadi media manusia mengenal Tuhan. Pada dasarnya, manusia harus memaksimalkan diri untuk memperoleh pengetahuan dengan usaha dan membersihkan dirinya.

\section{DAFTAR PUSTAKA}

Abdullah, "Hikmah Al-Israqiyah: Menelaah Sisi Eksistensialisme Teosofi Transenden Mulla Sadra", Sulesana, Vol. 7, No. 2, 2012.

Abdul Rahman Hj. Abdullah, Wacana Falsafah Ilmu: Analisis Konsep-konsep Asas Falsafah Pendidikan Negara, Malaysia: Sdn Bhd, 2005.

Aksin Wijaya, Satu Islam, Ragam Epistemologi, Yogyakarta: IRCiSoD, 2020.

Andi Safri Bachtiar, "Pemikiran Etika Mulla Sadra", Kuriositas, Vol. 11, No. 1, 2017.

Arsyad, "Mengenal Konsep Wujud Dalam Filsafat Mulla Sadra", Jurnal Bidayah, Vol. VIII, No. 2, 2017.

Badruzaman, Dudi. Perkembangan Paradigma Epistemologi Dalam Filsafat Islam. IDEA: Jurnal Humaniora, Vol 2, No.1, April 2019.

Dahlan Lama Bawa, "Pemikiran Pendidikan Mulla Sadra", Jurnal Tarbawi, Vol. 1, No $2,2017$.

Dhiauddin, "Aliran Filsafat Islam (Al-Hikmah Al-Muta'aliyah) Mulla Sadra”, Nizham, Vol. 01. No. 01, 2013.

Nasr, Seyyed Hossein. Al-Hikmah Al-Muta'aliyyah Mulla Sadra: Sebuah Terobosan dalam Filsafat Islam. Terj. Mustamin al Mandary. Jakarta: Sadra Press, 2017.

Nur, Syaifan. Filsafat Hikmah Mulla Shadra. Yogyakarta: RausyanFikr Institute, 2012.

Thabathaba'i, Muhammad Husayn. Bidayat al-Hikmat. Qom : Muasasat Nashr al-Islami, 1415.

-----. Nihayat al-Hikmat. Qom : Muasasat Nashr Islami, 1415.

Subhani, Ja'far. Nazhariyat al-Ma'rifat. Qom : Markaz al-Alami li al-Dirasat alIslamiyah, 1411.

Supratman, "Dimensi Sosial Dalam Filsafat Mulla Sadra”, Jurnal Ilmu Budaya, Vol.7, No.2, 2019.

Syaifan Nur, Filsafat Hikmah Mulla Sadra, Yogyakarta: RausyanFikr Institute, 2012.

Ulya, "Logika Wujud Șadra Meretas Nalar Radikalisme Beragama", Jurnal Theologia, Vol. 27, No.1, 2016. 